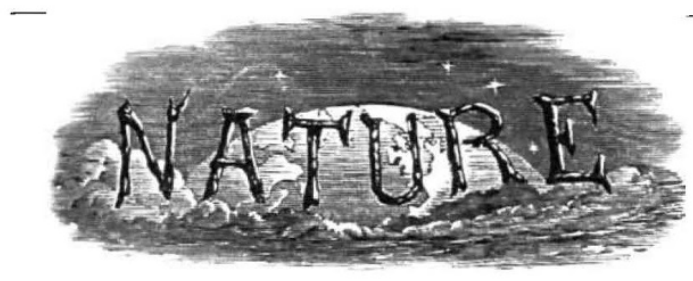

THURSDAY, AUGUST I8, I92I.

Editorial and Publishing Offices:

MACMILLAN \& CO., LTD.,

ST. MARTIN'S STREET, LONDON, W.C. 2.

Advertisements and business letters should be addressed to the Publishers.

Editorial communications to the Editor.

Telegraphic Address: PHUSIS, LONDON.

Telephone Number: GERRARD 8830.

\section{A Suggested Institute of Human Sciences.}

$\Upsilon^{N}$ the human sciences-those sciences which deal with the origin, the characters (physical, mental, and moral), and the activities of man: in other words, the anthropological sciences in the broadest sense of the term-co-ordination and cooperation are more essential than in almost any other branch of scientific research. This is due partly to the extent of the ground covered, and partly to the character of the subject-matter, which is frequently based upon a mass of data collected from a wide area. This necessity for co-operation, acting in conjunction with man's perennial interest in himself and his past, has led to the formation of a host of societies, each dealing with one or more branches of the subject. Some cover certain special aspects only-archæological, sociological, linguistic, psychological, and the like; others study man on a regional basis, and of these some cover the whole field more or less completely, as in the case of Asia and Africa; while still others confine themselves almost entirely to the archæological aspect, as in the case of the societies which deal with Egypt, Palestine, and the Mediterranean area.

The function of these learned societies in the main is fourfold. The societies serve as a gathering place for workers at which the latest results of research can be announced and discussed; they provide libraries which in theory contain books and periodicals not otherwise readily accessible NO. 2703, vOL. IO7] to their members; they act as the publishers of the work of their members, which, on the ground either of its specialist character or of its brevity, is not suitable for publication elsewhere or in book form, thereby assisting further in disseminating the results of scientific investigation; and, lastly, they further the interests of their subject by the promotion and organisation of research and by pressing its claims to support upon the public. There has been considerable variation in the measure of success with which these functions have been performed; but, speaking generally, as the affairs of the principal learned societies which deal with human studies are in the hands of those who have attained distinction in their subjects, they lead the way and exert a not inconsiderable influence upon the lines of development of further investigation.

Those, however, who are concerned with the administration of these societies are well aware that the position is not entirely satisfactory. There is very little co-operation between societies, although a few welcome, but tentative, steps in this direction have been taken. Not only does this restrict undertakings which for financial or other reasons are beyond the resources of a single society, but it also leads to a certain amount of overlapping. Most societies have a library; where several societies deal with cognate subjects, in certain sections the same books and periodicals appear in each. This is a waste of both space and money, whether the library is augmented entirely by purchase or in part by exchange. There is also a waste of the time, energy, and money of the worker. A paper dealing with a certain specific subject may appear in any one of half a dozen or more publications, and it is impossible to know in which of a number of libraries a certain book may be found. In one case a scientific worker who wished to make use in his laboratory of a certain book long out of print visited nearly every scientific society in London before he ran it to ground. He then had to join that society in order to borrow the book.

There is also the question of catalogues and bibliographies. Owing to the cost of printing, any catalogue which is to be of use to the members who live at a distance, and cannot visit the library, is an impossibility, while a bibliography of current literature on comprehensive lines seems equally impossible without greater eo-operation than has been secured up to the présent.

In addition to the cost of maintaining libraries, C C 
under the present system heavy expenditure is imposed upon each society by the necessity for providing suitable and adequate accommodation for meetings and lectures.

It is unnecessary to labour these points, which must be familiar to many. The difficulties do not date from to-day or yesterday, but at the moment they are more acutely felt. Under financial stress the activities and usefulness of scientific societies are being restricted. Increases in subscriptions do not counterbalance increase in costs. Individual workers also suffer; in many cases they have to confine their membership to the society to which their work is most closely related, thus restricting their outlook and their knowledge of current work.

It would, therefore, seem desirable to cast about for some remedy which might remove or mitigate these disabilities. This might be found in the union of a number of societies dealing with this group of studies to form an Institute of Human Sciences, housed in one building and governed by a supreme council, each society retaining such a measure of autonomy under its own committee as is consistent with the common aim. Considerable economies could then be effected by pooling the respective libraries, thus avoiding unnecessary expenditure on duplicating books, and to a certain extent by pooling the staff. The amount saved might be applied to increased expenditure on the library, on cataloguing, or on bibliographical work, for which the facilities would be greatly extended by the collection of the greater part of the material and the association of a number of specialists in various branches of study within the four walls of one building. The extent to which the various societies would be fused into one institution must depend upon circumstances; but it would probably be a gain if the publications were standardised and issued in series. It would not follow as a matter of course that each member would receive all the series; the issue would be confined to such only as he required. In fact, the issue of publications might well serve as a basis for regulating the amount of the subscription payable over and above the common fee of the institute admitting to the privilege of attendance at meetings, the use of the library, and other services.

That such an institute would greatly increase the resources at the disposal of the scientific worker is self-evident. Not only would he be brought more closely into touch with those investigating different aspects of the same problems NO. 2703 , VOL. IO7] as he himself is investigating, but he would also benefit in other ways. Although scientific investigation is becoming increasingly a matter of specialisation, yet in the anthropological sciences the interrelation of the different branches of study is becoming closer as the need for synthetic treatment is more fully appreciated. No student of the human sciences can afford to neglect results obtained in fields other than his own. Under the present system few have the time at their disposal to attend the meetings of all the societies with the work of which they should be acquainted, or to go through all their publications, even if these are accessible. Given an institution under one roof, organised to meet this need of the worker, with a common library and a common staff, and provided with an adequate bibliographical system, and he should have no excuse if he failed to obtain all that he required.

By a combination such as is indicated science would benefit in at least two directions. Under the control of a supreme council, which from its constitution would be in a position to survey the whole field, research could be organised on a scale and with a certainty of direction which have not yet been attained, while the financial assistance which such an association of interests might hope to command would be considerable. Further, the influence which this body could bring to bear upon public opinion would be such as far to outweigh anything of which the individual societies appear capable at present, however desirable or necessary the objects which they urge from time to time in connection with matters of public interest.

In education it is now becoming generally recognised that, in addition to the study of physical and mental characters, the data of the human sciences have an important bearing upon many of the subjects of the curriculum of both universities and schools, and can be applied with advantage in teaching even quite small children. At present the educationist or the teacher who is not acquainted with the results of specialist research outside the four corners of his own subject is at a loss in which direction to turn for trustworthy guidance. Such guidance it would be one, and that not the least important, of the functions of the institute to provide.

Finally, although this scheme of amalgamation, for obvious reasons, must, with possibly a few exceptions, be confined to societies now housed in London, there is every reason to hope that 
local societies throughout the country could participate to some degree. The local archæological societies have done good work, but in the present state of our knowledge there is great need that their work should be standardised and given direction on a more or less common basis. This object might be attained by a system of affiliation and co-operation, more close than any now existing, with some central body such as the institute here suggested.

\section{Astrology.}

(I) The Mediaeval Attitude toward Astrology, particularly in England. By Theodore Otto Wedel. (Yale Studies in English. No. 1x.) Pp. vii + 168. (New Haven: Yale University Press; London: Humphrey Milford: Oxford University Press, 1920.) Ios. $6 \mathrm{~d}$. net.

(2) Opera hactenus inedita Rogeri Baconi, Fasc. v. Secretum Secretorum cum glossis et notulis; Tractatus brevis et utilis ad declarandum quedam obscure dicta. By Fratris Rogeri. Nunc primum edidit Robert Steele. Accedunt versio Anglicana ex Arabico edita per A. S. Fulton. Versio retusta Anglo-Normanica nunc primum edita. Pp. 1xiv +317 . (Oxford: Clarendon Press.) 28s, net.

$7 \mathrm{HE}$ attitude of man towards Nature may be I said to have two stages-the "magical" and the "scientific." In the former, man lives in a world surrounded by other ill-defined beings and powers. From time to time he finds, or thinks he finds, some way to make these subserve his will, but he has as yet no apprehension of a constant relation of cause and effect. In the later, scientific stage--which first presents itself clearly to our view in the Ionian philosophers of the sixth century B.c.- a belief has arisen in natural law, in an invariable relation of cause and effect. Perhaps the most important step in the journey towards this belief was the discovery of the regularity in the movements of the heavenly bodies. The laws that these movements exhibit had long been the subject of organised observation in the Mesopotamian civilisations from which the Ionians inherited a wealth of data. But the Greeks had a passionate, almost an instinctive, belief in natural law, though few such laws had been demonstrated. Perceiving the majestic and regular recurrence of heavenly phenomena, they learned to predict them. They saw, too, that winter and summer, seed-time and harvest, day and night, and all the other broadly cyclic events of life, could be brought into some sort of relation with the heavenly cycle. Outside and beyond

$$
\text { No. 2703, VOL. IO7.] }
$$

these there were, indeed, innumerable less regular and unpredictable phenomena, for there was as yet no biology, no chemistry, practically no physics, and scarcely any mathematics. What more reasonable than to attribute a relation between the phenomena observed to be cyclic and those the laws of which were yet unknown? Natural laws there must be, and the field of the known was but extended into the unknown. Thus astrology was born.

Later a definite geocentric spherical system of the universe was introduced-a system that held its own right down to Copernicus and Galileo and beyond. The earth was surrounded by those mysterious concentric spheres in which the stars and planets held their place-the heavenly bodies considered by the greatest of the philosophers to be eternal and divine. Spatially the universe was limited; outside the outmost sphere was nothing; within the inmost sphere was the little world on which we live. To such a view the theory of astral and planetary control of our world was attractive, satisfying, well-nigh inevitable. It needed only verification, but verification was not the strong point of the scientific system of antiquity, still less of the Dark and Middle Ages which followed. The belief in the value of astrology thus remained almost universal from Greek times until the seventeenth century. It is unfair to regard it as a superstition. It is but a discarded and untenable scientific hypothesis.

Astrology, however, had a foe, and that foe was the Church, or rather the Churches. But the opposition of the Churches must not be accounted to them for scientific righteousness; rather it was the other way. The Churches were ever insistent on man's dependence on God. How, then, could man's existence be regulated by the action of the stars that were but God's creatures? Yet as time went on the opposition of all religions, Christian and other, gradually weakened. It became evident that even God Himself worked through agents, and why should not these agents be the stars that $\mathrm{He}$ had made? Thus room was made for the acceptance of astrological belief, which from patristic times onward gained steadily on men's minds. In the twelfth and thirteenth centuries, as the great Arabian revival of learning penetrated to the West, astrology became a highly elaborate science; by the fifteenth century, with the ebb of the scholastic movement, it had become a widespread obsession that infected alike the university, the council chamber, the law court, and the physician's consulting-room.

(I) The general history of this extraordinary 